\title{
«ТВОРЧИЙ НАЦІОНАЛІЗМ» МИКОЛИ ШЛЕМКЕВИЧА
}

У статті висвітлено основні ідейні конщепщії «творчого націоналізму» Миколи Шлемкевича - головного ідеолога політичної організації «Фронт національної едності» (ФНЄ). У другій половині 1930-х років ФНЄ був единою легальною націоналістичною партією Галичини та займав помітне місце в західноукраїнському політичному спектрі. На підставі головних праць Шлемкевича проаналізовано внесок мислителя в розвиток української суспільно-політичної думки XX століття.

Ключові слова: творчий націоналізм, Микола Шлемкевич, Фронт національної едності, український націоналізм.

Постановка проблели. Постать Миколи Шлемкевича займає особливе місце в суспільно-політичному житті міжвоєнної Галичини. Науковець, фрілософ, публіцист, редактор, видавець, громадський та політичний діяч, один із найосвіченіших українських інтелектуалів, що залишив по собі чималу кількість цікавих ідей, Шлемкевич, однак, залишаеться недооціненим як другий після Дмитра Донцова найважливіший український націоналістичний мислитель міжвоєнної доби.

В українській та закордонній історіографії ідеологія українського інтегрального націоналізму представлена переважно «чинним націоналізмом» Дмитра Донцова та «організованим націоналізмом» ОУН. Третій важливий напрям українського інтегрального націоналізму 1930-х рр. - «творчий націоналізм» «Фронту національної єдності» (ФНЄ), головним ідеологом якого був М. Шлемкевич, - залишається практично не дослідженим. Незважаючи на постійне наукове зацікавлення особою M. Шлемкевича-фрілософра, науковці у своїх працях

Козленко Сергій Володимирович, аспірант кафедри нової i новітньої історії України, Український католицький університет, м. Львів.

() Козленко С.В., 2017 
здебільшого оминали його діяльність в громадськополітичній площині. Чи не найменш вивченим періодом його життепису залишаються 1920-30-ті рр.

Стан дослідження. Загалом в історичній науці дослідження ідейної спадщини Шлемкевича перебуває на початковому етапі. На історіографічному рівні політична діяльність Шлемкевича, його внесок у становлення ФНС та творення ідеологї «творчого націоналізму» не стали об'єктом спеціальної уваги дослідників. Певні аспекти громадсько-політичної діяльності М. Шлемкевича висвітлювали у своїх працях I. Вдовичин, Н. Бурачок, I. Козій, Р. Демчишак. Окремо варто відзначити монографію Олександра Зайцева, в якій дослідник вперше здійснив спробу комплексно дослідити ідейну концепцію «творчого націоналізму» М. Шлемкевича в контексті розвитку ідеології українського інтегрального націоналізму [1, c. 339-374].

Метою цієї статті є висвітлити головні положення концепції "творчого націоналізму» М. Шлемкевича як феномену західноукраїнської дійсності міжвоєнної доби.

Виклад основного матеріалу. «Творчий націоналізм», розвиток та конщептуальне оформлення якого тривало до початку Другої світової війни, був офіційною ідеологічною платрормою ФНЄ. Основні ідейні засади «творчого націоналізму» Шлемкевич виклав у низці статей під псевдонімом «Микола Іванейко» в ідеологічному часописі Фронту «Перемога», редактором якого він був. Серед найголовніших варто виділити такі базові праці Шлемкевича: реферат «Ідеольогічні підстави творчого націоналізму», програмна стаття «Творчий націоналізм як фрілософія мілітанс», «Ідеольогічний редерат тов. М. Іванейка», виголошений на I конгресі ФНЄ 20 вересня 1936 р., та ін. [2; 3; 4].

Слід одразу зазначити, що Шлемкевич не створив власної, чітко сорормованої доктрини. Очевидно, 3 тієї причини, що його «творчий націоналізм» - лише спроба раціонально окреслити те, що сам він вважав ірраціональними, вольовими прагненнями української 
нації: «Найглибша українська проблема - це знайти дорогу раціонального офрормлення нашої волі в духовій культурі й державі» [5, с. 11].

Філософ чітко розмежовує поняття «народ» $\mathrm{i}$ «нація». Народ, за Шлемкевичем, - це кровно споріднена стала спільнота, об'єднана спільною мовою та звичаями, тимчасом, як нація - продукт історичного розвитку. Лише наявність спільної пам'яті, традицій та державотворчих прагнень свідчать про еволюційний перехід спільноти до найвищого ступеня національного розвитку [4, с. 7].

Шлемкевич сповідував націоналізм в інтегральному розумінні, що споріднювало його 3 Донцовим i теоретиками ОУН [1, с. 341]. Для націоналізму «першою дійсністю» $є$ нація, в якій окрема особа існує та має цінність лише як частина національного організму [6, с. 3]. У цьому сенсі націоналізм стає вирішальним чинником, що впорядковуе та довершуе формування нації: «Нащіоналізм [...] стоплює душевні атоми «вільного духа» в один характер, а молекули одиниць ліберальної суспільности переплавлюе в моноліт нації і таким чином уводить в історію невидані енергїі» [7, с. 3].

Націоналізм, твердив Шлемкевич, спрямовує людину до справжньої свободи. Цей шлях, насамперед, полягає в пробудженні національної віри та, як наслідок, у звільненні національної субстанщії, що становить ядро душі кожної людини. Лише усвідомлення власної національної сутності робить людину вільною [8, с. 2].

Нація, за Шлемкевичем, - це також стратифрікована структура, об'єднана спільними цілями та завданнями. Глибина сприйняття національної віри та здатність надати їй практичних форм становлять головний критерій, на підставі якого Шлемкевич сорормував модель суспільної ієрархії. Місія еліти - найпродуктивнішої ланки - підпорядкувати своїй волі несвідомі народні маси, що перебувають на середньому щаблі іерархічної структури, пробудити в них національну віру. Духовні раби, особи, позбавлені національної субстанції, становлять останню ланку суспільної ієрархії: «Рабом 
залишається тільки той, в кого немає, в кого загинула національна субстанція. Це невилічальні. Необхідно накинути їм не віру, але зовнішню поведінку, що відповідає поведінці вірних» [8, с. 1-2]. Саме ці ідеї дають підстави характеризувати націоналізм Шлемкевича як інтегральний [8; 9].

Стан українського суспільства міжвоенної доби Шлемкевич показав як боротьбу двох світів: «Проти себе стають два світи: один - світ організованого споживача, другий - світ націоналізму». Моральний світ споживача Шлемкевич описує як замкнутий в егоїстичних рамках шлях, цілковито позбавлений високих цілей. Головна цінність споживацтва - щастя, найбільшим втіленням якого $є$ добре оплачувана посада. В подібну ідейну систему координат, на думку Шлемкевича, найкраще вписуеться соціалістичне бачення прогресу [10, с. 2].

Натомість світ «творчого націоналізму», який має прийти на зміну споживацтву, Шлемкевич змальовує як аскетичний світ "правдивої моралі», що керуеться гаслом «Добро нації - найвищий наказ». Нація для мислителя головний посередник, через якого окрема особа може осягнути містичну божественну вічність, без якої життя позбавлене сенсу [10, с. 2-3].

Світ «творчого націоналізму» являє собою переоцінку цінностей і водночас переворот у суспільній іерархії: «На верхах стоять тут ті, що збірають, нагромаджують духову, політичну, господарську енергію нації». Шлемкевич передбачає неминучий конфлікт між цими двома світами, закликаючи послідовників українського націоналізму бути «спільнотою нового світогляду, нової моралі й нової одушевленої праці» [10, с. 3].

Інтелігенції фрілософ відводив важливу роль у формуванні провідної, елітної ланки суспільства й поділяв їі на дві категорії. До першої зараховував діячів, які, «гублячись у чужім, залишаються самовдоволеними наслідувачами»; до другої - тих, які «звертаються до заходу на те тільки, щоб навчитись оформлювати своє життя, свої глибини» [11, с. 4]. 
1927 року побачила світ праця відомого фрранцузького письменника та філософра Жульена Бенди «Зрада інтелектуалів», що спровокувала тривалі дискусії в міжвоєнній Свропі стосовно ролі та місця інтелектуалів у суспільстві. Бенда критикуе тогочасних фрранцузьких інтелектуалів, які відмовилися від своеї традиційної ролі духовних авторитетів, захопилися більш приземленими й водночас абстрактними ідеями та панівними політичними ідеологіями, що, своєю чергою, спричинило процес розмивання інтелігенції як окремого класу й морального підмурівка суспільства.

Одну 3 головних причин цього Бенда вбачає в метаморфозах сучасного світу, що перетворив інтелектуала на громадянина, поклавши на нього відповідні суспільні обов'язки. За спостереженнями Бенди, «нова віра інтелектуала» - це відчуття патріотизму щодо власної національної спільноти. За окремими винятками, істинні інтелектуали, на його думку, з'являються на територіях, де народи переживають бурхливі процеси націєтворення [12, с. 184-185].

Відлуння полеміки довкола праці Бенди відбилося на сторінках тогочасної польської преси. Ян Парандовський, відомий знавець античної культури, критикував Бенду за надмірну ідеалізацію образу «істинного інтелектуала» i пропонував авторові «Зради» поєднати його 3 поміркованим патріотизмом. Так само Александер Герц стверджував, що інтелектуала, який би погодився 3 твердженням Бенди, що його «царство не від світу цього», не існує в природі. Справжнім інтелектуалом, переконаний Герц, можна бути лише в конкретному місці та часі, у нерозривному зв'язку з контекстом доби [13, с. 219-221].

Шлемкевич поділяв критику інтелігенції за їі «зраду», однак вірив, що вона зможе осягнути покладену на неї місію провідника нації [14, с. 5]. Найвище завдання української інтелігенції, на думку мислителя, - сприяти створенню «лицарського ордену української стихійної волі самоздійснення, а не тільки клясових хотінь» та надати цій стихійній волі ідеологічного виразу й органічного 
втілення [14, с. 18 ; 1, с. 345]. Варто додати, що під цим орденом він розумів ФНЄ.

М. Шлемкевич негативно ставився до тогочасних політичних партій. Як штучні, раціональні утворення, партії, на переконання фрілософра, лише спотворюють об'єктивні закони природи [14, с. 16]. Партійним утворенням, які «ідейно та політично перестарілись, прикривають свою підтоптаність духовим вбранням модного фрасону», він протиставляе свій «творчий націоналізм» та його практичне втілення - «Фронт національної єдності» [15, с. 4].

Особливою рисою діяльності Фронту Шлемкевич вважає скерованість насамперед «до позитивної творчости, а не до голої негації», недвозначно натякаючи на Донцова й ОУН. Також, на відміну від Донцова, який наголошував на важливості зовнішньої політики, діяльність ФНЄ скеровано в ділянку внутрішньої політики [2, с. 7]. Цілком природно, що ФНЄ, який, за задумом Шлемкевича, втілював у собі синтез «револющійної ідеї нового українського світу з зорганізованою працею», протиставляв себе як «нетворчому» націоналістичному табору - Донцову та ОУН, так і демократам із УНДО [2, с. 3; 16, арк. 8].

Одним із основних завдань Фронту було об'єднання усіх верств населення під єдиним проводом організації: «Ф. Н. Є. - це властива надбудова клясократії, втілення всім клясовим групуванням спільної національної волі. Ф. Н. С. - це завершення кляс, їхня життездатна єдність у однім національнім тілі» [14, с. 23]. Слід наголосити, що В. Липинський під класократією розумів провідну верству, обрану з-поміж усіх прошарків суспільства, що присутня на всіх щаблях державної влади. Україна для Липинського - це насамперед потужний клас хліборобів, у яких він вбачає головного носія державної ідеї [17]. Загалом Шлемкевич визнавав слушність думок Липинського, але із застереженням ставився до його державотворчих поглядів, стверджуючи натомість, що втілити класократію в чистому вигляді неможливо [14, c. 11]. У цьому сенсі М. Шлемкевич використовує термін 
«клясократія» на позначення сукупності всіх груп та прошарків української нації, единим виразником органічного втілення прагнень яких він вважав ФНЄ.

Мислитель окреслює віхи української історії, спираючись на фрілософрську концепщію Гегеля з їі поділом на історичні та неісторичні народи, i дрормуе теорію двократного «завмирання й відродження» нації. Філософр зараховуе українців до молодих націй із давньою культурою та історією. За Шлемкевичем, фрормування української нації пройшло два етапи культурного піднесення та спроб створення повноцінної національної держави [18, с. 15]. У княжий період націю репрезентували нечисленні представники владної та інтелектуальної еліти. У Війську Запорозькому нація набула ширшого виразу, з нею ототожнювали все козацтво [4, с. 7].

Модерна доба ознаменувала початок третього періоду, коли народ стає носієм національних ідей, поступово перетворюючись на націю [4, с. 7]. У цьому полягала принципова різниця поглядів на процеси націєтворення у Миколи Шлемкевича та Дмитра Донцова. Для останнього лише нація як «ініціативна меншість» була в усі часи носієм національної ідеї. Здобуття власної держави має стати завершальним етапом становлення нації. Якщо нація загине втрете, вона не матиме шансів на відродження, хід історії буде неможливо зупинити [4, с. 8].

Як і ідеологи ОУН, М.Шлемкевич також обдумував шляхи синтезу націоналізму та релігії. Це питання мотивувалося не лише вимогою політичної доцільності - 3 огляду на духовну кризу, лише націоналізм i релігія залишалися єдиними носіями ідеї вічності, втраченої в новітні часи [7, с. $3 ; 1$, с. 354].

Римо-Католицька церква асоціюеться в Шлемкевича із колонізаційною політикою польської держави [4, с. 8]. Протилежним було ставлення фрілософра до православ'я. М. Шлемкевич відзначав важливу роль Православної церкви, яка в часи бездержавності була осередком націєтворення та хоронителем нечисленних представників нації. Однак це не стосувалося Греко-Католицької церкви, 
яка в минулому «...не була нинішньою українською католицькою церквою, але знаком наступаючого латинства». Метою українського релігійного відродження, вважав він, мало стати створення єдиної української церкви, зразком для якої слугувала б модель ГКЦ [18, с. 15].

I3 поступовим розвитком націетворчих процесів саме націоналізм мав стати новою, державною релігією української нації. У майбутній українській державі Церква мала займати другорядну позицію, повністю підпорядковуючись владі (або в часи бездержавності національному проводові). У разі виникнення конфрліктної ситуації лише влада як виразник інтересів нації мала право вказувати Церкві на помилки та скеровувати ї̈ діяльність у потрібне для національних інтересів русло [18, с. 15$]$.

М. Шлемкевич мав власне бачення розв'язання соціальних проблем. За мислителем, «націоналістичне розуміння життя», ідеальна суспільна модель нації - це солідаризм, синтез усіх продуктивних прошарків українського суспільства [19, с. 4]. На переконання Шлемкевича, раціональну основу української економіки становить кооперативний рух: «Кооперація - це одна з форм планового, розумового наладнання господарства. Серед наших

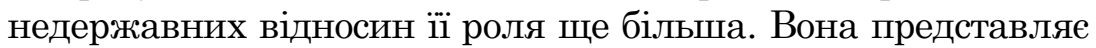
раціональний прінціп української економіки» [20, с. 11].

Спираючись на реалії тогочасної Галичини, Шлемкевич вважав прийнятною економічну модель, що базуеться на органічній співпраці кооперативного руху та приватних підприемців [20, с. 11]. Націоналізм, своєю чергою, має сприяти солідарній співпраці, що спрямована на захист економічних інтересів українства. Водночас М. Шлемкевич застерігав, що можливість конфлікту між кооперативним i приватним секторами українського національного господарства призведе до ослаблення хитких підвалин національного господарства [1, с. 357].

Економічний розвиток тісно переплітався 3 потребою урбанізації нації. Урбанізація - стрижневий модернізаційний елемент "творчого націоналізму», що відрізняє 
М. Шлемкевича від Д. Донцова та В. Липинського, перший з яких вважав селянство, а другий - хліборобський клас, до якого входили i селяни, i землевласники, основою майбутньої держави. Урбанізацію М. Шлемкевич окреслював як важливу передумову утворення держави. Відсутність переваги українського елемента в містах, на його думку, була однією з причин поразки в 1917-1920 рр. Також, на переконання мислителя, лише урбанізація шлях до справжнього осучаснення українців: «В тій ділянці дороги українського й західного націоналізмів розходяться. Там земельні реформи мають завдання [...] стримання нагальної урбанізації. Для нас навпаки, урбанізація, посилений відплив із села в місто стає не лише соціальним, але й основним національним питанням» [21, с. 5].

Політичні та культурні хитання між Свропою та Росією - фрактор, що розділяв націю, заважав їі сталому розвитку. М. Шлемкевич підкреслював важливість вирішення цієї постійної української дилеми. На противагу «окциденталізацї̈ України, яку сповідував Д. Донцов, він висуває ідею «метрополії духа» - духовної та культурної незалежності нації: «Український націоналізм вважає себе культурним явищем того самого роду, що новітні національні рухи Европи. Саме тому він мусить підкреслити свою духову свободу не лиш супроти сходу, але й заходу. Не українізована Росія, не українізована Свропа, але Україна без прикметника, як усебічний вияв своерідних глибин нації» [22, с. 3].

М. Шлемкевич вороже ставився до більшовицької Росії- змальовував радянський комунізм як світ «босяцьких душ московських кочовників» [7, с. 3]. «Большевики вдираються в душу народу, накидаючи їй свою московську комуністичну віру», - писав фрілософр. Внутрішній устрій Радянського Союзу він окреслював як темний, раціоналістичний світ "московського комунізму» [4, c. $8 ; 20$, с. 11$]$.

Натомість М. Шлемкевич бачив позитив у фрашизмі, вважав його виявом «віри [...] з душ інтелігентних середніх 
верств Італії й Німеччини», а також виявом світового революційного духу, в якому український націоналізм мав посісти своє окреме місце: «Кожен націоналізм має свою питому закраску. [...] Фашизм ставить в осередку своїх думок ясне поняття держави й разом 3 тим набірає раціоналістичнішого вигляду, ніж німецький національний соціялізм, де тон дає не зовсім ясне почуття раси, а держава стає лиш засобом збереження їі вияву. Провідний мотив українського націоналізму вийде 3 проблематики українського життя» [7, с. 3-4].

Утворення держави - лише перший етап утвердження українства на світовій арені. Національна ідея, місія України, на переконання Шлемкевича, полягає в повному утвердженні слов'янської культури, на що не спромігся жоден зі слов'янських народів. Мислитель наголошував, що реалізація української національної ідеї спричинить кардинальні зміни всього східноевропейського регіону: «Українська національна ідея до основ революційна. Самоздійснення української нації, в культурі та в державі, означає кінець давнього й початок нового, йнакшого світу на сході Свропи» [2, с. 4, 7].

Услід за Освальдом Шпенглером Микола Шлемкевич вважав, що культурний злет Свропи вже позаду, проте «спроможність європейського світу невичерпана ще в цивілізаторськім простірнім напрямі». 3 цієї перспективи фрілософр окреслює кінцеву, довготривалу мету майбутньої української держави: «Тож перед українським духом стоїть ... завдання: у своїй культурі здійснити те, що намагається здійснити нинішній захід у своїй цивілізації. Це наше европейство: починати там, де Свропа кінчає й таким чином із комірника стати спадкоємцем європейського духа» [23, с. 10].

Висновки. «Творчий націоналізм» був доволі цікавим явищем в суспільно-політичному житті Галичини міжвоєнної доби. У своїх працях М. Шлемкевич порушував широке коло проблемних питань, окреслював шляхи їх вирішення, що вважав необхідною передумовою подальшого розвитку української нації. Подібно до Д. Донцова, М. Шлемкевич 
сповідував нащіоналізм в інтегральному розумінні, проте 3 певними засадничими відмінностями. Неприйняття й заперечення політичних партій та ідеологій, домінування національного солідаризму, посилена економічна експансія та урбанізація, вважав мислитель, мають на меті мобілізувати націю до тривалої боротьби. Проте формальне здобуття державності, за Шлемкевичем, не було головною метою націоналістів. Українська національна ідея, на його думку, у найширшому розумінні полягає в остаточному утвердженні слов'янської культури. Подальший культурний розвиток та експансія українства, вважав М. Шлемкевич, мають зафіксувати перевагу України на просторі Східної Свропи. Феномен "творчого націоналізму» Шлемкевича потребує подальших досліджень із залученням широкої джерельної бази.

1. Зайцев $O$. Український інтегральний націоналізм (1920-1930-ті роки): Нариси інтелектуальної історії. - К.: Критика, 2013. - 488 с.

2. Іванейко $M$. Ідеольогічні підстави творчого націоналізму (Реферат виголошений на 1 Краєвій Конференції Ф.Н. С. дня 23 березня 1935 р.) / М. Іванейко // Перемога. - 1935. - Ч. 30 - 1 квітня. C. $3-8$.

3. Іванейко $M$. Творчий націоналізм як філософрія мілітанс / М. Іванейко // Перемога. - 1935. Ч. 35 (9). - С. $5-10$.

4. Ідеольогічний реферат тов. М. Іванейка [виголошений на I конгресі Ф.Н.С. 20 вересня 1936 р.] / М. Іванейко // Перемога. - 1936. - Ч. 3. - С. 4-15.

5. Іванейко $M$. Про ірраціоналізм, чудернацьке словянство й европейських рецензентів / М. Іванейко // Перемога. - 1935. - Ч. 32 (6). - С. 10-12.

6. Іванейко $M$. Життя й ідеал / М. Іванейко // Перемога. - 1934. - Ч. 8. - С. 3-4.

7. Іванейко М. Націоналізм (Фраимент статті «Недоля духа й націоналізм») / М. Іванейко // Перемога. 1933. - Ч. 1. - C. 3-4.

8. Іванейко M. Наша свобода / M. Іванейко // Перемога. - 1934. - Ч. 6. - С. 1-3.

9. Під інтегральним націоналізмом я розумію шовіністичну, праву форму націоналізму, що 
розглядає націю як органічну цілість, вимагає цілковитого підпорядкування особистості націоналњним інтересам, які знаходяться вище від інтересів будь-якої іншої соціальної групи і нації. (Іванейко M. Наша свобода / М. Іванейко // Перемога. - 1934. - Ч. 6. - С. 2.)

10. Іванейко M. Два світи / М. Іванейко // Перемога. 1935. - Ч. 28. - C. 2-3.

11. Іванейко $M$. За шлях у гору / M. Іванейко // Перемога. - 1934. - Ч. 14. - С. 3-4.

12. Бенда Ж. Предательство интеллектуалов. - М.: ИРИСЭН, Мысль, Социум, 2009. - 310 с.

13. Jan Zikba, Czy klerk istnieje? Miкdzywojenne spory o rolк inteligencji w spoieczecstwie // Metamorfozy spoieczne. Nr. 4: Kultura i spoieczecstwo II Rzeczypospolitej. Warzsawa: Instytut Historii PAN. S. 217-232.

14. Іванейко $M$. Проблєма української інтелігенції (Інтелігенція й політика) / М. Іванейко // Перемога. - 1936. - Ч. 2. - С. 1-19.

15. Іванейко $M$. Друге покоління i нащадки / М. Іванейко // Перемога. - 1934. - Ч. 11. - С. 4-5.

16. Державний архів Львівської області. - Ф. 7 (Львівське повітове староство, м. Львів Львівського воєводства). - Оп. 2. - Спр. 1103.

17. Українська державність у XX столітті: історикополітологічний аналіз [Електронний ресурс] / Ред. кол.: О. Дергачов, Є. Бистрицький, О. Білий, I. Бураковський, Дж. Мейс, В. Полохало, М. Томенко та ін. - К.: Політ. думка, 1996. - Режим доступу: http://litopys.org.ua/ukrxx/zmist.htm.

18. Іванейко $M$. Рецензія (А. Річинський: Проблема української релігійної свідомости) / М. Іванейко // Перемога. - 1934. - Ч. 20. - С. 14-15.

19. Іванейко $M$. Життя й ідеал / М. Іванейко // Перемога. - 1934. - Ч. 8. - С. 3-4.

20. Іванейко $M$. Ідея й господарство / М. Іванейко // Перемога. - 1935. - Ч. 29. - С. 10-12.

21. Іванейко M. Світ і дім / М. Іванейко // Перемога. 1934. - Ч. 9. - С. 5-6.

22. Іванейко M. Метрополія духа й націоналізм // Перемога. - 1933. - Ч. 2. - С. 2-4.

23. Іванейко $M$. Українська фрілософрія (Питання української духової культури 3 націоналістичного погляду) / М. Іванейко // Перемога. - 1935. - Ч. 27. C. 9-11. 
Надійшла до редколегії 16.12.2016 p.

Рецензент: Ю.В. Бураков, кандидат історичних наук, доцент, провідний науковий співробітник Наукового центру Сухопутних військ, Національна академія сухопутних військ імені гетьмана Петра Сагайдачного, м. Львів.

\section{Козленко С.В. «ТВОРЧЕСКИЙ НАЦИОНАЛИЗМ» НИКОЛАЯ ШЛЕМКЕВИЧА}

В статье отражены основные идейные концепщии «творческого национализма» Николая Шлемкевича - главного идеолога политической организации «Фронт национального единства» (ФНЕ). Во второй половине 1930-х годов ФНЕ был единственной легальной националистической партией в Галичине и занимал видное место в западноукраинском политическом спектре. На основании главных работ Шлемкевича проанализирован вклад мыслителя в развитие украинской общественно-политической мысли XX века.

Ключевые слова: творческий национализм, Николай Шлемкевич, Фронт национального единства, украинский национализм.

\section{Kozlenko S.}

«CREATIVE NATIONALISM» OF MYKOLA SHLEMKEVYCH

This article highlights the most important ideas and concepts of "creative nationalism» of Mykola Shlemkevych, who was the main ideologist of a political organization named Front of National Unity (FNU). FNU was the only legal nationalistic political party in Galicia in the second half of 1930s and had quite a visible place in western Ukrainian political specter. Mykola Shlemkevych's contribution into development of Ukrainian social and political thought of XX century is analyzed based on his major works.

Keywords: creative nationalism, Mykola Shlemkevych, Front of National Unity, Ukrainian nationalism. 